\title{
COMPARISON OF DIRECT IMMUNOFLUORESCENCE, CONVENTIONAL CELL CULTURE AND POLYMERASE CHAIN REACTION TECHNIQUES FOR DETECTING RESPIRATORY SYNCYTIAL VIRUS IN NASOPHARYNGEAL ASPIRATES FROM INFANTS
}

Alexanda Dias REIS(1), Maria Cristina Domingues FINK(1), Clarisse Martins MACHADO(1), José de Paula PAZ Jr.(1), Renato Reis OLIVEIRA(1), Adriana Fumie TATENO(1), Adriana Freire MACHADO(1), Maria Regina CARDOSO(2), Claudio Sérgio PANNUTI(1) \& The CHIADO AND RDGV/FAPESP RESEARCH GROUPS

\section{SUMMARY}

A total of 316 samples of nasopharyngeal aspirate from infants up to two years of age with acute respiratory-tract illnesses were processed for detection of respiratory syncytial virus (RSV) using three different techniques: viral isolation, direct immunofluorescence, and PCR. Of the samples, 36 (11.4\%) were positive for RSV, considering the three techniques. PCR was the most sensitive technique, providing positive findings in 35/316 (11.1\%) of the samples, followed by direct immunofluorescence $(25 / 316,7.9 \%)$ and viral isolation $(20 / 315,6.3 \%)$ ( $<$ < 0.001). A sample was positive by immunofluorescence and negative by PCR, and 11 (31.4\%) were positive only by RT-PCR. We conclude that RT-PCR is more sensitive than IF and viral isolation to detect RSV in nasopharyngeal aspirate specimens in newborn and infants.

KEYWORDS: Respiratory syncytial virus; Infants; Diagnosis; Cell culture; Polymerase chain reaction; Immunofluorescence.

\section{INTRODUCTION}

The respiratory syncytial virus (RSV) is considered to be the most common viral agent of lower respiratory tract infections in infants and young children, and can cause serious respiratory illnesses ${ }^{5,712,20}$.The highest morbidity rates are observed in infants, in the elderly and in the immunocompromised $d^{4,9,17,18,22}$. Viral isolation in cell cultures continues to be considered the most definitive test for diagnosis ${ }^{6}$. However, rapid techniques such as antigen detection by direct immunofluorescence (IF) employing monoclonal antibodies, and reverse transcriptase-polymerase chain reaction (RT-PCR) have been used increasingly to detect the virus in clinical samples. The sensitivity of RT-PCR can equal or exceed that of cell culture or antigen-based assays ${ }^{6}$. Several studies underline the impact of the use of rapid techniques on the clinical evolution of patients compared with conventional techniques ${ }^{2}$. In immunocompromised patients, especially bone marrow transplant recipients and premature neonates, this is particularly important since these patients require prompt therapeutic intervention ${ }^{8}$. In addition, rapid diagnosis allows early implementation of RSV-infection control policies, thus reducing nosocomial infections. The objective of this study was to compare the sensitivity of three techniques for the detection of RSV in respiratory secretions: viral isolation, direct immunofluorescence using monoclonal antibodies, and RT-PCR.

\section{MATERIAL AND METHODS}

Population and samples: The samples analyzed in this study came from a prospective cohort consisting of 173 healthy newborns followed up from birth up to twenty-four months of age. The main objective of that earlier study was to evaluate risk factors for the development of wheezing diseases. Nasopharyngeal aspirates were collected whenever they presented with signs/symptoms of acute respiratory infection as long as the symptoms had been present for no more than five days. No child required hospitalization during the study.

Nasopharyngeal aspirate collection: Two milliliters of Ringer's lactate were introduced into each nostril with a silicon tube and vacuum aspirated in a sterile collector ${ }^{8}$. The samples, kept at $4{ }^{\circ} \mathrm{C}$, were promptly sent to the laboratory and processed within two hours for direct immunofluorescence (IF) and viral isolation. An aliquot of the aspirate was stored in liquid nitrogen for subsequent RT-PCR.

Viral isolation: Human laryngeal epithelial carcinoma (Hep2) cell line was used for viral isolation. Samples were inoculated in one tube kept in a roller drum (one rotation per minute at $33^{\circ} \mathrm{C}$ ) to ensure uniform circular movement. RSV isolation was confirmed by using specific monoclonal antibodies (Imagen ${ }^{\circledR}$, DAKO, Cambridgeshire, UK). In the absence of a cytopathic effect by the tenth day after inoculation, a

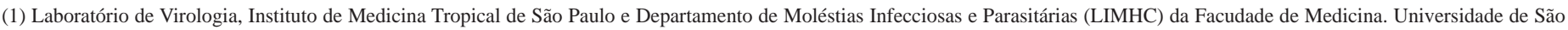
Paulo. Av. Dr. Enéas de Carvalho Aguiar 470, 05403-000 São Paulo, SP, Brazil.

(2) Departmento de Epidemiologia da Faculdade de Saúde Pública da Universidade de São Paulo. Av. Dr. Arnaldo 715, 01246-904 São Paulo, SP, Brazil.

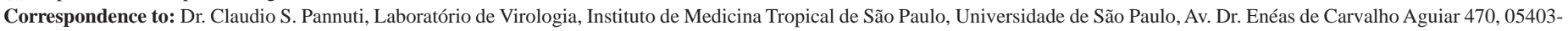
000 São Paulo, SP, Brazil. Tel: 55-11-3061.7020, Fax: 55-11-3063.2659. E-mail: cpannuti@usp.br 


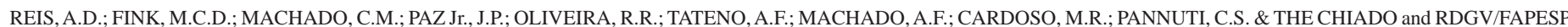
RESEARCH GROUPS - Comparison of direct immunofluorescence, conventional cell culture and polymerase chain reaction techniques for detecting respiratory syncytial virus in nasopharyngeal aspirates from infants. Rev. Inst. Med. trop. S. Paulo, 50(1): 37-40, 2008.

blind passage was performed and the tubes were kept for a further ten days. In negative cases a second blind passage was performed

Direct immunofluorescence: The direct immunofluorescence technique was performed using specific monoclonal antibodies against RSV (Imagem ${ }^{\circledR}$, DAKO, Cambridgeshire, UK) in accordance with the manufacturer's instructions.

Reverse transcriptase-polymerase chain reaction ( $R T-P C R)$ : Molecular detection of RSV was performed using a nested RT-PCR technique. RNAs from the standard and clinical samples were extracted using aliquots prepared in Trizol ${ }^{\circledR}$ and stored at $-80{ }^{\circ} \mathrm{C}$. Two hundred and fifty microliters of nasopharyngeal aspirates were mixed with $750 \mu \mathrm{L}$ of Trizol $^{\circledR}$ and $200 \mu \mathrm{L}$ of chloroform. The upper phase was precipitated with $400 \mu \mathrm{L}$ of isopropanol for $15 \mathrm{~min}$. After centrifugation, the pellet was washed with $70 \%$ ethanol, air dried, and finally resuspended in DEPC treated water.

The reverse transcription step was performed prior to the PCR assay using the High-Capacity cDNA Archive ${ }^{\circledR}$ kit (Applied Biosystems, Foster City, CA, USA) in accordance with the manufacturer's instructions.

The nested PCR amplification protocol standardized employs complementary mRNA primers of the $G$ and $F$ glycoproteins with primers described elsewhere: first round - FV gttatgacactggtataccaac, GAB ycaytttgaagtgttcaactt ${ }^{13,24}$. The PCR mixture $(50 \mu \mathrm{L})$ contained $5 \mu \mathrm{L}$ of cDNA, deoxynucleotide triphosphates at a concentration of $1.25 \mathrm{mM}, 10 \mathrm{pmol}$ of primers, $1 \times$ reaction buffer $(10 \mathrm{mM}$ tris, $50 \mathrm{mM}$ $\mathrm{KCl}$ ), $1.5 \mathrm{mM} \mathrm{MgCl}_{2}, \mathrm{Taq}$ polymerase $2.0 \mathrm{U} /$ reaction. First-round PCR cycle conditions consisted of five min at $95^{\circ} \mathrm{C}$ for denaturation, and 35 cycles of one min at $94^{\circ} \mathrm{C}$, one min at $55^{\circ} \mathrm{C}$, one min at $72{ }^{\circ} \mathrm{C}$ and a final elongation step for seven min at $72{ }^{\circ} \mathrm{C}$, using a thermal cycler (Eppendorf). For the second-round PCR, $5 \mu \mathrm{L}$ of the first-round PCR was used as template DNA and the same conditions were applied, but another set of primers was used: F1AB caactccattgttatttgcc, GAB ycaytttgaagtgttcaactt ${ }^{13,14}$. All PCR reactions were performed under stringent conditions to avoid contamination: three separate rooms were used to prepare amplification mix, to apply DNA to the Eppendorf tubes and to run the agarose gels, respectively; and each PCR run contained several negative controls (containing water instead of DNA templates).

RT-PCR analytic sensitivity: To estimate the analytic sensitivity of the PCR, a fragment amplified from the F and G glycoproteins was cloned in accordance with the manufacturer's instructions (pGEM ${ }^{\circledR}$ T Easy Vector Systems, Promega Corporation, Madison, USA).

The degree of sensitivity of the PCR amplification method was estimated by amplifying decreasing dilutions of cloned DNA. This method was able to detect as few as 100 copies of RSV.

Sequencing: The samples positive for RSV using the RT-PCR technique were confirmed by sequencing to exclude non-specific amplification. The DNA strands were sequenced using the Big Dye ${ }^{\circledR}$ Terminator v 3.1 Cycle Sequencing kit (Applied Biosystems, Foster City, CA, USA) in accordance with the manufacturer's instructions. The nucleotide and amino acid sequences corresponding to the G2 region were aligned in two groups, A and B, using the MegAlign ${ }^{\mathrm{TM}}$ 4.05 - Expert Analysis Software - DNAStar program. This procedure estimated the degree of similarity between the sequences calculated pair by pair, and allowed identification of identical nucleotide sequences.

Statistical analysis: Fisher's exact test was used to analyze the sensitivity of the three techniques. Differences were considered statistically significant when $\mathrm{p}$ was less than 0.05 .

\section{RESULTS}

A total of 316 samples collected between December 2003 and September 2005 were analyzed during the study. Of these, 36 (11.4\%) were positive for RSV by at least one technique. Regarding the total number of samples processed, RT-PCR was positive in 35 (11.1\%), immunofluorescence was positive in 25 (7.9\%) and viral isolation was positive in 20 (6.3\%) (Table 1). Among the 36 RSV positive samples, 20 (57.1\%) were positive by the three techniques used, and four (11.4\%) were positive by IF and RT-PCR. One of the samples was positive by immunofluorescence alone, and 11 (31.4\%) were positive only by RTPCR.

Table 1

Proportion of nasopharyngeal aspirate samples positive or negative for RSV by RT-PCR, viral isolation and immunofluorescence techniques

\begin{tabular}{llll}
\hline & RT-PCR & ISO & DFA \\
\hline POS & $35(11.1 \%)$ & $20(6.3 \%)$ & $25(7.9 \%)$ \\
NEG & $281(88.9 \%)$ & $295(93.7 \%)$ & $291(92.1 \%)$ \\
Total & 316 & 315 & 316 \\
\hline
\end{tabular}

$\overline{\text { DFA - Direct immunofluorescence assay; ISO - viral isolation; NEG - negative; }}$ POS - positive.

All the 29 samples that could be sequenced were confirmed as RSV group $A(n=21)$ or $B(n=8)$. The similarity between the sequences varied from 86 to $100 \%$. Of the 29 sequences analyzed 23 (79.3\%) were not $100 \%$ similar. However, three sets of identical sequences were obtained. One set was present in four samples, one in three samples, and the other in two samples. None of the samples in the sets was processed by PCR on the same day.

Viral isolation was positive in 20/315 (6.3\%) samples. A sample could not be processed by virus isolation. Regarding the efficiency of the blind passages after the first negative passage culture, it was found that in 3/315 cases negative after the first passage, a cytopathic effect (CPE) was seen after the second passage. In another three samples, the CPE was observed only after a third blind passage. All the other 309 samples processed using viral isolation (including the 16 samples positive by other techniques) still gave negative results, despite being subjected to two blind passages. The use of two blind passages thus raised the overall positivity rate in cell cultures from 14/315 (4.4\%) to 20/315 (6.3\%). Considering RT-PCR as the gold standard, viral isolation achieved a sensitivity of $58.8 \%$, specificity of $100 \%$, positive predictive value (PPV) of 100\%, and negative predictive value (NPV) of $95.2 \%$ compared with RT-PCR. Regarding the use of IF for RSV detection, 


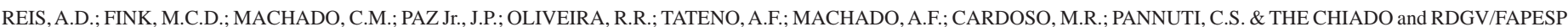
RESEARCH GROUPS - Comparison of direct immunofluorescence, conventional cell culture and polymerase chain reaction techniques for detecting respiratory syncytial virus in nasopharyngeal aspirates from infants. Rev. Inst. Med. trop. S. Paulo, 50(1): 37-40, 2008.

Table 2

Comparison of RT-PCR, immunofluorescence techniques and viral isolation in cells culture for detecting RSV in nasopharyngeal aspirate samples

\begin{tabular}{lllllll}
\hline & & DFA $(\mathrm{n}=316)$ & & \multicolumn{2}{c}{ ISO $(\mathrm{n}=315)^{*}$} \\
RT PCR & Positive & Negative & Total & Positive & Negative & 14 \\
\hline Positive & 24 & 11 & $35^{* *}$ & 20 & 0 & 281 \\
Negative & 01 & 280 & 281 & 20 & 295 & 281 \\
Total & 25 & 291 & 316 & 315 \\
\hline
\end{tabular}

DFA - Direct immunofluorescence assay; Sensitivity $=69.44 \%$; Specificity $=99.66 \%$; PPV $=96.0 \%$ and NPV $=96.2 \%$; ISO $=$ viral isolation; Sensitivity $=58.8 \%$, Specificity $=100 \%, \mathrm{PPV}=100 \%$ and NPV $=95.2 \%$. $*$ One sample could not be processed by viral isolation. $* *$ p value $<0.001$.

we obtained a sensitivity of $69.4 \%$, specificity of $99.7 \%$, PPV of $96.0 \%$ and NPV of $96.2 \%$ compared with the RT-PCR technique (Table 2).

\section{DISCUSSION}

Despite the increasing use of antigen detection by IF with monoclonal antibodies and of RT-PCR to detect RSV in clinical samples, isolation of the virus in cell culture is still considered the most definitive test for laboratory diagnosis ${ }^{5,6}$. As observed in other comparative studies ${ }^{19,21,23}$, RT-PCR was significantly more sensitive than viral culture, and antigen testing, for the detection of RSV in nasopharyngeal aspirate samples. Considering RT-PCR as the gold standard, the viral isolation technique was the less sensitive technique for diagnosis of RSV infection. Although blind passage has been performed for RSV and other viruses in some laboratories ${ }^{1,21}$ we could not find data in the literature concerning its true effectiveness. In our study, $30 \%$ of the cases diagnosed by virus isolation could be detected only after blind passages, highlighting the contribution of additional passages to increase the sensitivity of this technique. However, considering all the samples examined in the present study, the positivity rate among all clinical samples raised from 4.4 to $6.3 \%$ overall. In view of the costs and labor involved, the use of this procedure in routine diagnostics is highly questionable in terms of cost-benefit though it could be justified in studies in which the recovery of the virus is an essential step.

There is a clear trend towards the use of techniques that allow early diagnosis of RSV infection. Early diagnosis is advantageous because it permits the implementation of measures to limit the spread of the virus (for example, in a hospital setting or nursing home), and early implementation of antiviral therapy. In our study, even with only one passage, viral isolation only allowed diagnosis from the third day after inoculation, making this technique unsuitable for RSV diagnosis, particularly in patients who would clearly benefit from early therapeutic intervention. Immunofluorescence (IF), on the other hand, is widely used to detect RSV in epithelial nasopharyngeal cells because it is faster and less laborious than isolation. However, the IF technique requires a sample rich in cells, expertise in handling an immunofluorescence microscope ${ }^{10}$ and is less sensitive than RTPCR $^{18,20,22}$. Our in house RT PCR could detect as few as $100 \mathrm{RSV}$ copies, and this analytic sensitivity is similar to RT assays used in other studies ${ }^{16}$. We excluded the possibility of non-specificity of the RT-PCR assay using sequencing to confirm samples that were positive for RSV. Furthermore, to exclude the possibility of amplicon contamination, we aligned the sequenced PCR products with sequences corresponding to the G2 region of the gene encoding the A- and Bgroup RSV G protein, which revealed individual differences between the sequences amplified by PCR.

The choice of a technique is of the utmost importance for the rapid and sensitive diagnosis of RSV. Our findings suggest that RT-PCR is more effective than IF and viral isolation in diagnosing RSV infection. The recent application of real-time PCR in respiratory specimens has shown to be a rapid and sensitive alternative to conventional RT-PCR and rapid antigen detection assays for RSV detection ${ }^{2,11,15}$ and may contribute to the definitive replacement of virus isolation in cell cultures for diagnosis of viral respiratory infections.

\section{RESUMO}

Comparação entre imunofluorescência direta, cultura convencional de células e reação em cadeia de polimerase para detectar vírus respiratório sincicial em lavados de nasofaringe de crianças

Um total de 316 amostras de lavado de nasofaringe obtidas de crianças em acompanhamento ambulatorial com até dois anos de idade durante episódio de doença aguda do trato respiratório foram processadas para detecção do vírus sincicial respiratório (VSR) utilizando três diferentes técnicas: isolamento viral, imunofluorescência direta e reação em cadeia por polimerase (RT-PCR). Destas amostras, $36(11,4 \%)$ foram positivas para o VSR. A RT-PCR foi a técnica mais sensível, com positividade em 35 (11,1\%) das amostras, seguindo-se a imunofluorescência direta (25/316, 7,9\%) e o isolamento viral (20/ 315, 6,3\%) ( $<<0,001)$. Uma amostra foi positiva pela imunofluorescência e negativa pela RT-PCR, e 11/36 (31,4\%) foram positivas somente pela RT-PCR. Concluímos que a RT-PCR é mais sensível que a imunofluorescência e o isolamento viral para detecção do VRS em amostras de aspirado de nasofaringe de recém-nascidos e lactentes.

\section{ACKNOWLEDGEMENTS}

Supported by FAPESP (grant 2002/08465-8) and CNPQ (grant 620001/02-0).

We thank Laura M Sumita and Dr. Paulo C. Cotrim for the construction of the plasmid for in-house PCR evaluation and Michela G. de Marqui for the screening of the samples. 


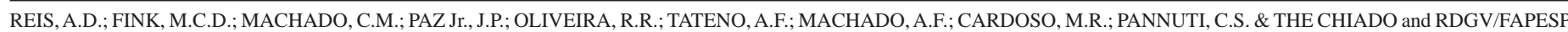
RESEARCH GROUPS - Comparison of direct immunofluorescence, conventional cell culture and polymerase chain reaction techniques for detecting respiratory syncytial virus in nasopharyngeal aspirates from infants. Rev. Inst. Med. trop. S. Paulo, 50(1): 37-40, 2008.

\section{REFERENCES}

1. AhluWALiA, G.; EMBREE, J.; McNiCOL, P.; LAW, B. \& HAMMOND, G.W. Comparison of nasopharyngeal aspirate and nasopharyngeal swab specimens for respiratory syncytial virus diagnosis by cell culture, indirect immunofluorescence assay, and enzyme-linked immunosorbent assay. J. clin. Microbiol., 25: 763-767, 1987.

2. BARENFANGER, J.; DRAKE, C.; LEON, N.; MUELLER, T. \& TROUTT, T. - Clinical and financial benefits of rapid detection of respiratory viruses: an outcomes study. $\mathbf{J}$. clin. Microbiol., 38: 2824-2828, 2000.

3. BOIVIN, G.; COTE, S.; DERY, P.; DE SERRES, G. \& BERGERON, M.G. - Multiplex real-time PCR assay for detection of influenza and human respiratory syncytial viruses. J. clin. Microbiol., 42: 45-51, 2004.

4. CALEGARI, T.; QUEIROZ, D.A.; YOKOSAWA, J. et al. - Clinical-epidemiological evaluation of respiratory syncytial virus infection in children attended in a public hospital in Midwestern Brazil. Braz. J. infect. Dis., 9: 156-161, 2005

5. CINTRA, O.A.; OWA, M.A.; MACHADO, A.A. et al. - Occurrence and severity of infections caused by subgroup A and B respiratory syncytial virus in children in southeast Brazil. J. med. Virol., 65: 408-412, 2001.

6. COLLINS, P.L. \& CROWE, J.E. - Respiratory syncytial virus and metapneumovirus. In: KNIPE, D.M. \& HOWLEY, P.M. Fields Virology. 5. ed. Philadelphia, Lippincott, Williams and Wilkins, 2007. p. 1601-1646.

7. DINIZ, E.M.; VIEIRA, R.A.; CECCON, M.E.; ISHIDA, M.A. \& VAZ, F.A. - Incidence of respiratory viruses in preterm infants submitted to mechanical ventilation. Rev. Inst. Med. trop. S. Paulo, 47: 37-44, 2005.

8. ENGLUND, J.A.; PIEDRA, P.A.; JEWELL, A. et al. - Rapid diagnosis of respiratory syncytial virus infections in immunocompromised adults. J. clin. Microbiol., 34: 1649-1653, 1996.

9. FALSEY, A.R. \& WALSH, E.E. - Respiratory syncytial virus infection in elderly adults. Drugs Aging, 22: 577-587, 2005.

10. KUMAR, M.L.; SUPER, D.M.; LEMBO, R.M.; THOMAS, F.C. \& PROKAY, S.L. Diagnostic efficacy of two rapid tests for detection of respiratory syncytial virus antigen. J. clin. Microbiol., 5: 873-875, 1987.

11. MENTEL, R.; WEGNER, U.; BRUNS, R. \& GURTLER, L. - Real-time PCR to improve the diagnosis of respiratory syncytial virus infection. J. med. Microbiol., 52: 893896, 2003.

12. OGRA, P.L. - Respiratory syncytial virus: the virus, the disease and the immune response. Paediat resp. Rev., 5(suppl. A): 119-126, 2004.

13. PERET, T.C.; HALL, C.B.; HAMMOND, G.W. et al. - Circulation patterns of group A and B human respiratory syncytial virus genotypes in 5 communities in North America. J. infect. Dis., 181: 1891-1896, 2000.
14. PERET, T.C.; HALL, C.B.; SCHNABEL, K.C.; GOLUB, J.A. \& ANDERSON, L.J. Circulation patterns of genetically distinct group A and B strains of human respiratory syncytial virus in a community. J. gen. Virol., 79: 2221-2229, 1998.

15. PERKINS, S.M.; WEBB, D.L.; TORRANCE, S.A. et al. - Comparison of a real-time reverse transcriptase PCR assay and a culture technique for quantitative assessment of viral load in children naturally infected with respiratory syncytial virus. J. clin. Microbiol., 43: 2356-2362, 2005.

16. PIERANGELI, A.; GENTILE, M.; Di MARCO, P. et al. - Detection and typing by molecular techniques of respiratory viruses in children hospitalized for acute respiratory infection in Rome, Italy. J. med. Virol., 79: 463-468, 2007.

17. RABONI, S.M.; NOGUEIRA, M.B.; TSUCHIYA, L.R. et al. - Respiratory tract viral infections in bone marrow transplant patients. Transplantation, 76: 142-146, 2003.

18. RICCETTO, A.G.; RIBEIRO, J.D.; SILVA, M.T. et al. - Respiratory syncytial virus (RSV) in infants hospitalized for acute lower respiratory tract disease: incidence and associated risks. Braz. J. infect. Dis., 10: 357-361, 2006.

19. ROVIDA, F.; PERCIVALLE, E.; ZAVATTONI, M. et al. - Monoclonal antibodies versus reverse transcription-PCR for detection of respiratory viruses in a patient population with respiratory tract infections admitted to hospital. J. med. Virol., 75: 336-347, 2005

20. STRALIOTTO, S.M.; SIQUEIRA, M.M.; MACHADO, V. \& MAIA, T.M. - Respiratory viruses in the pediatric intensive care unit: prevalence and clinical aspects. Mem. Inst. Oswaldo Cruz, 99: 883-887, 2004.

21. WEINBERG, G.A.; ERDMAN, D.D.; EDWARDS, K.M. et al. - Superiority of reversetranscription polymerase chain reaction to conventional viral culture in the diagnosis of acute respiratory tract infections in children. J. infect. Dis., 189: 706-710, 2004.

22. WHIMBEY, E. \& GHOSH, S. - Respiratory syncytial virus infection in immunocompromised adults. Curr. clin. Top. infect. Dis., 20: 232- 255, 2000.

23. VAN ELDEN, L.J.; VAN KRAAIJ, M.G.J.; NIJHUIS, M. et al. - Polymerase chain reaction is more sensitive than viral culture and antigen testing for the detection of respiratory viruses in adults with hematological cancer and pneumonia. Clin. infect. Dis., 34: 177-183, 2002.

24. ZHENG, H.; PERET, T.C.; RANDOLPH, V.B.; CROWLEY, J.C. \& ANDERSON, L.J. Strain-specific reverse transcriptase PCR assay: means to distinguish candidate vaccine from wild-type strain of respiratory syncytial virus. J. clin. Microbiol., 34: 334-337, 1996.

Received: 18 May 2007

Accepted: 3 October 2007 